\title{
Ear Leaf Photosynthesis and Related Parameters of Transgenic and Non-GMO Maize Hybrids
}

\author{
H. Arnold Bruns \\ USDA-ARS Crop Production Systems Research Unit, P.O. Box 350, Stoneville, MS 38776, USA \\ Correspondence should be addressed to H. Arnold Bruns; arnold.bruns@ars.usda.gov
}

Received 12 November 2014; Revised 10 December 2014; Accepted 10 December 2014

Academic Editor: Manuel Tejada

Copyright ( $) 2015$ H. Arnold Bruns. This is an open access article distributed under the Creative Commons Attribution License, which permits unrestricted use, distribution, and reproduction in any medium, provided the original work is properly cited.

\begin{abstract}
Hybrid maize (Zea mays L.) through transgenics now includes $\delta$-endotoxins for insect control and tolerance to the herbicides glyphosate and glufosinate. Some hybrids have multiple transgenic traits as part of their genotype (stacked gene). Limited information is available on how these traits alone affect $A$ (net assimilation rate; $\mu \mathrm{mol} \mathrm{CO}_{2} \mathrm{~m}^{-2} \mathrm{~s}^{-1}$ ) and related physiological parameters. A two-year, two-location, irrigated experiment comparing four stacked gene, four glyphosate tolerant, and two nonGMO hybrids for ear leaf $A, g_{s}$ (stomatal conductance; mol $\mathrm{H}_{2} \mathrm{O} \mathrm{m}^{-2} \mathrm{~s}^{-1}$ ), Em (transpiration; mol $\mathrm{H}_{2} \mathrm{O} \mathrm{m}^{-2} \mathrm{~s}^{-1}$ ), IWUE (intrinsic water use efficiency; $\left(A /\left(g_{s} * 100\right)\right)$ ), and $\mathrm{C}_{i}$ (intercellular $\left[\mathrm{CO}_{2}\right] \mu \mathrm{mol} \mathrm{CO} \mathrm{Col}_{2}{ }^{-1}$ ) was completed at Stoneville, MS, in 2012. Data were collected at growth stages R1 (anthesis) and R2 (early kernel filling) using a Li-Cor LI-6400XT set at $355 \mu \mathrm{mol} \mathrm{mol}^{-1} \mathrm{CO}_{2}$ with a flow rate of $500 \mu \mathrm{mol} \mathrm{s}{ }^{-1}$ and a $6400-02$ light source set at $87.5 \%$ full sunlight. Measurements were made between $08: 30 \mathrm{~h}$ and 11:30 h CST, within $48 \mathrm{~h}$ of $25 \mathrm{ha} \mathrm{mm}$ irrigation and $\geq 33.0 \%$ cloud cover. Transgenic traits did not influence the physiological parameters of $A, g_{s}, E m$, IWUE, or $\mathrm{C}_{i}$ during the critical growth stages of R1 or R2.
\end{abstract}

\section{Introduction}

Maize with its extensive use for food, feed, and industrial products, especially biofuel ethanol, has resulted in the crop having the greatest volume of production of any cereal in the world [1]. The species has undergone many genotypic changes over the past century due to being cross pollinated and its comparative ease in hybridization. Extensive use of recently developed molecular genetic techniques has resulted in maize hybrids with multiple insect resistance by way of $\delta$ endotoxins from races of the bacteria Bacillus thuringiensis (Bt) and exclusive herbicide tolerance, glyphosate, and/or glufosinate ammonium, for control of weeds. Adding multiple traits developed by genomics to a maize hybrid's genotype is referred to as "stacking." Stacking adds to a plant's ability to resist attacks of several destructive insects and the choice of using glyphosate and/or glufosinate for weed control, two herbicides that are lethal to maize without the engineered genetic trait. However, stacking adds to the costs of seed as these "value-added" traits have patent protection in the countries where they are grown and technology fees are assessed the growers who purchase those hybrids.
The impact these value-added traits have on maize's physiological systems is not fully documented. Some studies on the effects of transgenic insect resistance by way of Bt events have been reported for cotton (Gossypium hirsutum L.) [2-5]. Most reported no difference in the physiological parameters of $A$ (net assimilation rate; $\mu \mathrm{mol} \mathrm{CO} \mathrm{m}^{-2} \mathrm{~s}^{-1}$ ), $g_{s}$ (stomatal conductance; $\mathrm{mol} \mathrm{H}_{2} \mathrm{O} \mathrm{m}^{-2} \mathrm{~s}^{-1}$ ), $\mathrm{Em}$ (transpiration; $\mathrm{mol} \mathrm{H}_{2} \mathrm{O}$ $\mathrm{m}^{-2} \mathrm{~s}^{-1}$ ), and $\mathrm{C}_{i}$ (intercellular $\left[\mathrm{CO}_{2}\right] ; \mu \mathrm{mol} \mathrm{CO} \mathrm{Col} \mathrm{air}^{-1}$ ) in leaves of $\mathrm{Bt}$ and nontransgenic cotton. Sun et al. [5] did however report a difference in $A$ between $\mathrm{Bt}$ and non-Bt cotton at the seedling growth stage.

Some of the effects of both glyphosate and glufosinate on physiological processes of tolerant crops are documented. Both herbicides are very toxic to nontolerant crops and have been the target compounds for transgenic development of tolerant cultivars due to their wide spectrum control of weed species. The metabolite of glyphosate, aminomethylphosphonic acid (AMPA), produced in both susceptible and resistant soybeans after herbicide application was found to reduce $A, g_{s}$, and $E m$ while increasing $C_{i}$ in soybean (Glycine max L. Merr.) [6]. Plants treated with $1.0 \mathrm{~kg} \mathrm{ha}^{-1}$ of 
glyphosate took up to $28 \mathrm{~d}$ before the measured metabolic rates returned to the equivalent to those of the controls. Glyphosate applied to barley (Hordeum vulgare (L.)) during grain filling at $0.1 \mathrm{~kg} \mathrm{ha}^{-1}$, which is $\leq 1.0 \%$ of the normal rate for weed control, increased grain yields by $12-15 \%$ with no apparent adverse effect on grain quality [7]. Wendler et al. [8] reported that glufosinate under atmospheric conditions $\left(400 \mu \mathrm{mol} \mathrm{mol}^{-1} \mathrm{CO}_{2}\right.$ and $210 \mathrm{~mL} \mathrm{~L}^{-1} \mathrm{O}_{2}$ ) causes an inhibition of $A$ in both $\mathrm{C}_{3}$ and $\mathrm{C}_{4}$ plants but that it proceeds slower in $\mathrm{C}_{4}$ maize leaves. Bruns and Abbas [9] compared LAI, CGR, yield, and yield components of glyphosate tolerant, glufosinate tolerant, and non-GMO (atrazine tolerant) maize hybrids treated with their respective herbicides to plots receiving only cultivation for weed control. No differences in any of the measured parameters were noted between plants receiving herbicide treatments for weed control and those that were only cultivated.

Most research on GMO maize has involved applications of the specific herbicides at various levels and/or the effects the insect pests controlled by the $\delta$-endotoxins have upon yield. Little information is available about how the presence of the genetic trait or traits alone, without the presence of the herbicides or pests, may be influencing some of the physiological parameters of the plant when compared to non-GMO hybrids. The objective of this experiment was to determine if the presence of multiple insect resistant traits, combined with glyphosate and/or glufosinate tolerance in maize hybrids (stacked gene; SG) or glyphosate tolerance only (GT), affects $A, g_{s}, E m, C_{i}$, and IWUE (intrinsic water use efficiency $\left.\left(A /\left(g_{s} * 100\right)\right)\right)$ compared to non-GMO maize hybrids.

\section{Materials and Methods}

The experiment was conducted during the 2011 and 2012 growing seasons at two sites near Stoneville, MS. One was a Bosket fine sandy loam (BFSL) (fine-loamy, mixed, active, thermic Mollic Hapludalfs) located on the Mississippi State University Delta Branch Research and Extension Center, and the other a Tunica clay (TC) (clayey over loamy, smectitic, nonacid, thermic Vertic Haplaquept) located on private property leased by the Crop Production Systems Research Unit of the USDA-ARS. This study was part of one designed to compare the economics of growing SG versus GT versus non-GMO maize with furrow irrigation [10].

Ten hybrids, four SG, four GT, and two non-GMO, were grown at both locations in randomized complete block designs replicated four times with a nested treatment structure consisting of the three genotype groups and the 10 hybrids nested within genotype. The hybrids grown for this research are listed in Table 1 along with their genotype and days to maturity. Both sites were seeded in $102 \mathrm{~cm}$ rows using a four-row John Deere model 7100 vacuum planter (John Deere Inc., Moline, Illinois) at a rate of 89,660 kernels $\mathrm{ha}^{-1}$ with a final stand goal of 76,570 plants $\mathrm{ha}^{-1}$. Weed control was achieved using Lexar (S-metolachlor (19.0\%) + atrazine $(18.6 \%)+$ atrazine related products $(0.39 \%)+$ mesotrione $(2.44 \%)$ ) applied preemergence at the rate of
TABLE 1: Maize hybrids, their genotype (stacked gene, SG; glyphosate tolerant, GT; non-GMO), and maturity rating (d) grown under furrow irrigation at two sites, a Bosket fine sandy loam and a Tunica clay soil at Stoneville, MS, in 2011 and 2012.

\begin{tabular}{lcc}
\hline Hybrid (genotype) $^{\dagger}$ & Added traits & Maturity (d) \\
\hline Pioneer 31G96 (SG) & HX1, LL, and RR2 & 117 \\
Dekalb DKC 66-96 (SG) & GENVT3Pro & 116 \\
Dekalb DKC 67-21 (SG) & GENVT3Pro and RR2 & 117 \\
Pioneer 31P42 (SG) & HX1, LL, and RR2 & 119 \\
Dekalb DKC 67-22 (GT) & RR2 & 117 \\
Pioneer 31P40 (GT) & RR2 & 119 \\
Pioneer 1615R (GT) & RR2 & 116 \\
Pioneer 33N55 (GT) & RR2 & 113 \\
Pioneer 33N56 (non-GMO) & None & 113 \\
Pioneer 31P41 (non-GMO) & None & 119 \\
\hline
\end{tabular}

GENVT3Pro $=$ Genuity VT Triple PRO RIB Complete (3 modes of insect protection, herbicide tolerance, and refuge in a bag).

$\mathrm{RR} 2$ = glyphosate tolerant.

$\mathrm{HX} 1=$ Herculex 1 insect protection ( 3 modes of insect protection).

$\mathrm{LL}=$ glufosinate tolerant.

non-GMO = nongenetically modified. Traditional genetics.

${ }^{\dagger}$ Pioneer Hybrids (DuPont Pioneer, Johnston, IA).

${ }^{\dagger}$ Dekalb Hybrids (Monsanto Co., St. Louis, MO).

$7.01 \mathrm{ha}^{-1}$. Neither glyphosate nor glufosinate was applied for postemergence weed control to avoid injury to the non-GMO hybrids and avoid any growth regulator effect these herbicides may have had. Insecticides were not needed during the course of the experiment. Liquid $\mathrm{N}$ fertilizer $\left(\mathrm{NH}_{4} \mathrm{NO}_{3}\right.$ : urea) was applied at a rate of $220 \mathrm{~kg} \mathrm{ha}^{-1}(\mathrm{~N})$ at growth stage V4 (fourth leaf fully extended) as defined by Ritchie et al., [11]. No other fertilizer applications were required according to preplant soil tests. The experiment was cultivated both years at growth stage V6 (sixth leaf fully extended) to provide some weed control and to clear irrigation furrows.

Ear leaf $A, g_{s}, E m$, WUE, and $\mathrm{C}_{i}$ were measured on three randomly selected plants from each plot at each location at growth stages R1 (anthesis) and $14 \mathrm{~d}$ later at R2 (blister, early kernel filling). Data were determined using a Li-Cor LI-6400XT Portable Photosynthesis System (LiCor Biosciences; Lincoln, NE) with a 6400-02(B) LED light source. A $0.6 \mathrm{~cm}^{2}$ leaf surface area was sampled with the cuvette while chamber temperature was set at $22.5^{\circ} \mathrm{C}$. Leaf chamber $\mathrm{CO}_{2}$ levels were controlled by using a $\mathrm{CO}_{2}$ cartridge and a fixed flow rate of $500 \mu \mathrm{mol} \mathrm{s}{ }^{-1}$. Reference $\left[\mathrm{CO}_{2}\right]$ within the leaf chamber was fixed at $355 \mu \mathrm{mol} \mathrm{mol}{ }^{-1}$ which was determined to be the mean atmospheric $\mathrm{CO}_{2}$ level for the region at the initiation of the experiment. The chamber temperature was maintained at $22.5^{\circ} \mathrm{C}$. Light levels, generated by the LED sources, were set at an indicated $1750 \mu \mathrm{mol} \mathrm{m}{ }^{-2} \mathrm{~s}^{-1}$ photosynthetic photon flux density (PPFD) which is approximately $87.5 \%$ full sunlight. All measurements were collected between $08: 30 \mathrm{~h}$ and 11:30 h CST, within $48 \mathrm{~h}$ of an irrigation of $25 \mathrm{ha} \mathrm{mm}$, and $\geq 33.0 \%$ cloud cover to avoid presampling stomatal closure due to poor light levels. Mean ear leaf $A, g_{s}, E m$, IWUE, and $C_{i}$ were determined for each plot. Data across years and site were 
combined and analyzed using the PROC MIXED procedure of the Statistical Analysis System 9.4 (SAS Institute, Cary, $\mathrm{NC}$ ). Years and sites were considered fixed effects while replications (years) were considered to be random. A regression analysis was performed to determine the relationship between $E m$ and $g_{s}$.

\section{Results and Discussion}

The hybrid $\mathrm{X}$ site interaction was significant $(P \leq 0.05)$ for mean $A$ rates at growth stage R1 but not for R2 (Figure 1). At the TC site the hybrid 31G96, an SG cultivar, had an A rate significantly greater than all other hybrids except 31P41, a non-GMO cultivar. At the BFSL site $A$ for $31 G 96$ was significantly less than $33 \mathrm{~N} 55$, a GT cultivar. Photosynthesis rates at R1 for the TC site were greater for 31G96, DKC 67-21, $1615 \mathrm{R}$, and 31P41 than they were for the BFSL site. No other significant differences among hybrids for $A$ in the hybrid $\mathrm{X}$ site interaction or the hybrid $\mathrm{X}$ year interaction were noted at R1. No statistically significance at growth stage R2 as was observed for the hybrid X year or the hybrid X site interaction.

Mean $A$ rates were higher at both growth stages at both sites in 2012 than 2011 (Table 2). According to weather records near the two sites, the greater mean levels of $A$ observed in 2012 than 2011 were likely due to there being more rainfall and/or irrigation prior to and during measurements taken in 2012 compared to 2011 [12]. Beginning $14 \mathrm{~d}$ prior to the first collection of data in 2011 and continuing up to the final set of observations, a total of $133.1 \mathrm{ha} \mathrm{mm}$ of water was received on both sites, $101.6 \mathrm{~mm}$ of that as irrigation. In $2012 \mathrm{a}$ total of 214.6 ha $\mathrm{mm}$ was received during data collection with only $25.4 \mathrm{~mm}$ being in the form of irrigation. In $2011 \mathrm{~A}$ was significantly $(P \leq 0.05)$ less at $\mathrm{R} 2$ for both sites than at $\mathrm{R} 1$ and greater for the TC site than the BFSL site. These higher mean levels of $A$ in 2012 at the TC site though did not translate into higher grain yields for that year over 2011 [10].

The site $\mathrm{X}$ year interaction was statistically significant $(P \leq 0.05)$ for $g_{s}$ at both R1 and R2 (Table 3). Stomatal conductance was less for plants grown on the BFSL site than the TC site in both years and both growth stages. The only other significant difference in $g_{s}$ was between 2011 and 2012 on the BFSL at R2 where $g_{s}$ in 2012 was greater than 2011. No such differences were observed for the TC site. None of the main effects on interactions involving hybrids or genotypes were found to differ significantly for $g_{s}$.

The site $\mathrm{X}$ year interaction was statistically significant $(P \leq 0.05)$ for Em for both R1 and R2 (Table 4). Except at R1 in 2012, Em was greater for plants growing on the TC than the BFSL. Rates of $E m$ at R2 were also greater than R1 on the TC both in 2011 and 2012. No significant difference was noted for Em at R1 in 2012 between the TC and BFSL sites. No significant differences in Em were noted between hybrids or genotypes and their interactions. Differences observed in Em closely paralleled $g_{s}$ as would be expected (Figure 2). Increased Em was significantly $(P \leq 0.05)$ and positively $\left(\mathrm{R}^{2}=0.8606\right)$ associated with increased $g_{s}$. The greater $g_{s}$ values would allow for a greater loss of water vapor from the leave tissue $(E m)$.

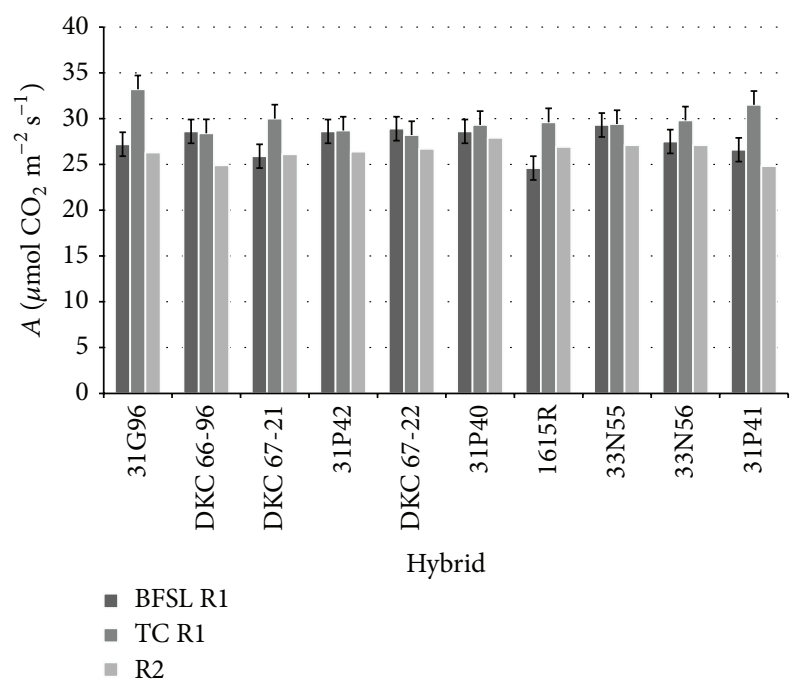

Figure 1: Mean $A$ at growth stages R1 and R2 of 10 maize hybrids grown under furrow irrigation on sites, a Bosket fine sandy loam (BFSL) and a Tunic clay (TC) soil near Stoneville, MS, in 2011 and 2012. Means of 3 plants, 4 replications, and 2 years for all data. Means for R1 are for 1 site, while for R2, 2 sites. Only means at growth stage R1 were significantly different $(P \leq 0.05( \pm \mathrm{SD}=1.51))$.

TABLe 2: Mean $A$ at growth stages R1 and R2 of 10 irrigated maize hybrids grown on a Bosket fine sandy loam (BFSL) and a Tunica clay (TC) soil in 2011 and 2012 near Stoneville, $\mathrm{MS}^{\dagger}$.

\begin{tabular}{lccccc}
\hline \multirow{2}{*}{ Year } & \multicolumn{5}{c}{$A\left(\mu\right.$ mols $\left.\mathrm{CO}_{2} \mathrm{~m}^{-2} \mathrm{~s}^{-1}\right)$} \\
& BFSL & & TC & BFSL & TC \\
\hline 2011 & 23.4 & 28 & 20.5 & 24.7 \\
2012 & 31.5 & 30.6 & 29.6 & 30.1 \\
\hline
\end{tabular}

${ }^{\dagger}$ Means of 3 plants, 10 hybrids (Pioneer 31G96, 31P42, 31P40, 1615R, 33N55, 33N56, and 31P41; Dekalb DKC 66-96, DKC 67-21, and DKC 67-22), and 4 replications. To compare means within a column or a row $\operatorname{lsd}_{0.05}=1.4$.

TABLE 3: Mean $g_{s}$ at growth stages R1 and R2 of 10 irrigated maize hybrids grown on a Bosket fine sandy loam (BFSL) and a Tunica clay (TC) soil in 2011 and 2012 near Stoneville, MS ${ }^{\dagger}$.

\begin{tabular}{lccccc}
\hline \multirow{2}{*}{ Year } & & \multicolumn{4}{c}{$g_{s}\left(\mathrm{~mol} \mathrm{H}_{2} \mathrm{O} \mathrm{m}^{-2} \mathrm{~s}^{-1}\right)$} \\
& BFSL & TC & BFSL & R2 \\
\hline 2011 & 0.34 & 0.53 & 0.27 & 0.55 \\
2012 & 0.4 & 0.48 & 0.39 & 0.48 \\
\hline
\end{tabular}

${ }^{\dagger}$ Means of 3 plants, 10 hybrids (Pioneer 31G96, 31P42, 31P40, 1615R, 33N55, 33N56, and 31P41; Dekalb DKC 66-96, DKC 67-21, and DKC 67-22), and 4 replications. To compare means within a column or a row at both growth stages, $1 \mathrm{dd}_{0.05}=0.07$.

Mean IWUE was found only to be statistically significant $(P \leq 0.05)$ for the site $\mathrm{X}$ year interaction at R1. No significant differences in IWUE were observed at R2, for hybrids, genotypes, or any of their interactions at either growth stage. In 2011 mean IWUE was greater for the BFSL site than the TC site at R1 (Table 5). In 2012 no differences in IWUE were observed between sites. However, IWUE was significantly 
TABLE 4: Mean Em at growth stages R1 and R2 of 10 irrigated maize hybrids grown on a Bosket fine sandy loam (BFSL) and a Tunica clay soil in 2011 and 2012 near Stoneville, $\mathrm{MS}^{\dagger}$.

\begin{tabular}{|c|c|c|c|c|}
\hline \multirow{3}{*}{ Year } & \multicolumn{4}{|c|}{$\operatorname{Em}\left(\mathrm{mol} \mathrm{H}_{2} \mathrm{O} \mathrm{m}^{-2} \mathrm{~s}^{-1}\right)$} \\
\hline & \multicolumn{2}{|c|}{$\mathrm{R}^{\ddagger}$} & \multicolumn{2}{|c|}{$\mathrm{R} 2^{\S}$} \\
\hline & BFSL & $\mathrm{TC}$ & BFSL & TC \\
\hline 2011 & 6.25 & 8.83 & 5.94 & 9.21 \\
\hline 2012 & 7.43 & 7.54 & 7.6 & 9.08 \\
\hline
\end{tabular}

${ }^{\dagger}$ Means of 3 plants, 10 hybrids (Pioneer 31G96, 31P42, 31P40, 1615R, 33N55, 33N56, and 31P41; Dekalb DKC 66-96, DKC 67-21, and DKC 67-22), and 4 replications.

${ }^{\ddagger}$ To compare means within a column or a row $1 s d_{0.05}=1.0$.

${ }^{\S}$ To compare means within a column or a row $1 \mathrm{ls}_{0.05}=0.8$.

TABLE 5: Mean WUE at growth stage R1 of 10 irrigated maize hybrids grown on a Bosket fine sandy loam (BFSL) and a Tunica clay (TC) soil in 2011 and 2012 near Stoneville, MS ${ }^{\dagger}$.

\begin{tabular}{lccc}
\hline Year & \multicolumn{3}{c}{ WUE } \\
\hline 2011 & BFSL & TC \\
2012 & 0.40 & 0.33 \\
\hline
\end{tabular}

${ }^{\dagger}$ Means of 3 plants, 10 hybrids (Pioneer 31G96, 31P42, 31P40, 1615R, 33N55, 33N56, and 31P41; Dekalb DKC 66-96, DKC 67-21, and DKC 67-22), and 4 replications. To compare means within a column or a row $\operatorname{lsd}_{0.05}=0.03$.

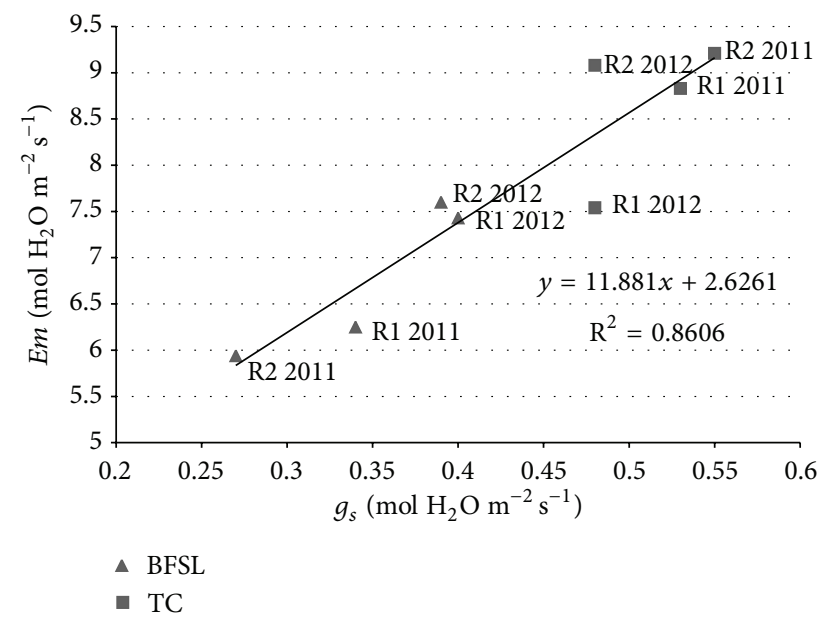

FIgURE 2: Regression of mean $E m$ to $g_{s}$ at growth stages R1 and R2 of 10 maize hybrids grown under furrow irrigation on a Bosket fine sandy loam (BFSL) and a Tunic clay (TC) soil near Stoneville, MS, in 2011 and 2012. Each data point represents the mean of 10 hybrids, 3 plants, and 4 replications at one growth stage and one site per year.

greater in that year than in 2011 for both the BFSL and TC sites. As discussed previously, in 2011 higher $g_{s}$ at the TC site compared to the BFSL site was observed (Table 3). According to Brady [13], a sandy loam soil such as a the BFSL site will have a water holding capacity of approximately $80 \mathrm{~mm} \mathrm{~m}^{-3}$ of available water compared to $125 \mathrm{~mm} \mathrm{~m}^{-3}$ of available water for a clay soil such as at the TC site. These possible differences in available soil water help explain the observed differences in $g_{s}$ in 2011 which would have influenced IWUE differences

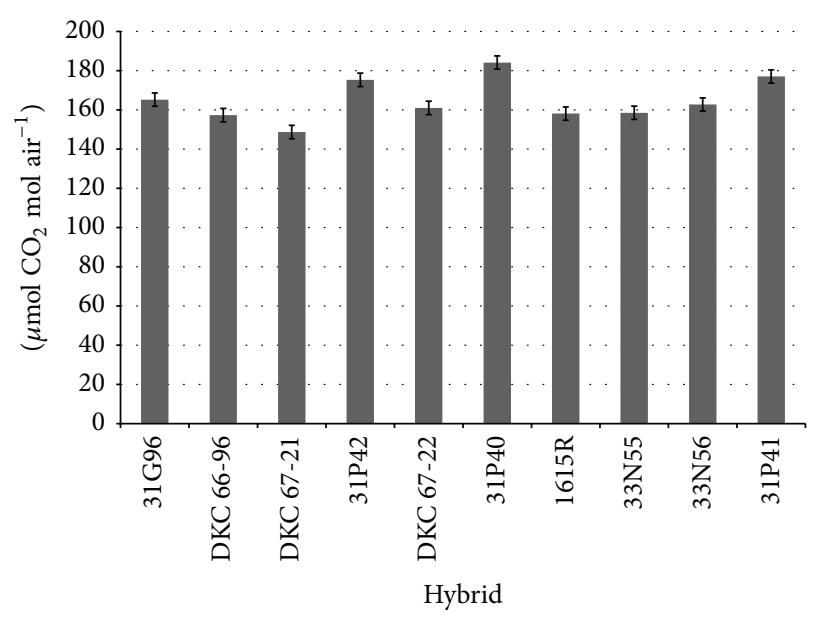

FIgURE 3: Mean $\mathrm{C}_{i}$ at growth stage $\mathrm{R} 1$ of 10 irrigated maize hybrids grown on a Bosket fine sandy loam and Tunica clay soil near Stoneville, MS. Means of 3 plants, 4 replications, 2 sites, and 2 years (2011 and 2012) $(P \leq 0.05( \pm \mathrm{SD}=10.8))$.

observed that year. In 2012 such differences were not observed probably because the amount of rainfall and irrigation, as previously mentioned, negated any advantage in available soil water the TC site likely had over the BFSL.

Intercellular $\left[\mathrm{CO}_{2}\right]$ at $\mathrm{R} 1$ differed significantly $(P \leq 0.05)$ among hybrids, sites, and years but not among genotypes, nor were any of the interactions of the main effects statistically significant. The greatest $\mathrm{C}_{i}$ 's were found in at least one hybrid from all three genotypes (Figure 3). The hybrids 31P40 (a GT), 31P41 (a non-GMO), and 31P42 (an SG) were significantly $(P \leq 0.05)$ greater in $C_{i}$ than most of the other hybrids in the experiment but not significantly different in $\mathrm{C}_{i}$ among each other. With respect to sites, the mean $\mathrm{C}_{i}$ for the TC site was greater $\left(180.1 \mu \mathrm{mol} \mathrm{CO} \mathrm{mol} \mathrm{air}^{-1}\right)$ than the mean for the BFSL site $\left(151.1 \mu \mathrm{mol} \mathrm{CO} \mathrm{mol} \mathrm{air}^{-1}\right)$ and mean $\mathrm{C}_{i}$ at $\mathrm{R} 1$ in 2011 was greater $\left(174.7 \mu \mathrm{mol} \mathrm{CO}_{2} \mathrm{~mol} \mathrm{air}^{-1}\right)$ than in 2012 $\left(156.5 \mu \mathrm{mol} \mathrm{CO} \mathrm{mol} \mathrm{air}^{-1}\right)$. At R2 only the main effects for $\mathrm{C}_{i}$ of site and year and its interaction were statistically significant $(P \leq 0.05)$. No significant differences were observed among genotypes, hybrids, or their interactions. Mean $C_{i}$ at $\mathrm{R} 2$ was greater for plants produced on the TC site in both years (213.6 and $175.1 \mu \mathrm{mol} \mathrm{CO} \mathrm{mol} \mathrm{air}^{-1}$ for 2011 and 2012, resp.) than for the BFSL site $\left(158.6\right.$ and $156.4 \mu \mathrm{mol} \mathrm{CO} \mathrm{mol} \mathrm{air}^{-1}$ for 2011 and 2012, resp.). The difference in $\mathrm{C}_{i}$ between the two sites was greater in 2011 than in 2012 . The $C_{i}$ between years at the TC site differed significantly while plants grown at the BFSL site did not differ in $\mathrm{C}_{i}$ between 2011 and 2012.

These data demonstrate that the transgenic traits incorporated into the maize hybrids to impart insect resistance and herbicide tolerance do not appear to influence the physiological traits of $A, g_{s}, E m$, WUE, or $\mathrm{C}_{i}$ during the critical growth stages of anthesis (R1) or early kernel filling (R2). Yield advantages that may result from growing a genetically modified hybrid maize most likely will be due to control of insect pests by the modification, good levels of weed control achieved by the herbicides the crop is genetically modified to 
tolerate, or a combination of both, such as what was found in stacked gene hybrids.

\section{Disclaimer}

Trade names are used in this publication solely for the purpose of providing specific information. Mention of a trade name, propriety product, or specific equipment does not constitute a guarantee or warranty by the USDA-ARS and does not imply approval of the named product to the exclusion of other similar products.

\section{Conflict of Interests}

The author declares that there is no conflict of interests regarding the publication of this paper.

\section{References}

[1] FAOSTAT, "Food and agriculture organization of the United Nations," 2014, http://faostat.fao.org/site/339/default.aspx.

[2] C. X. Sun, J. J. Hao, J. Wang, L. Miao, Z. H. Chen, and H. Qi, "Responses of photosynthetic physiological characteristics of two transgenic cotton (Gossypium hirsutum L.) varieties to $\mathrm{CO}_{2}$ concentration," Acta Ecologica Sinica, vol. 30, no. 2, pp. 504-510, 2010.

[3] H. Z. Dong, W. J. Li, W. Tang, Z. H. Li, and D. M. Zhang, "Effects of genotypes and plant density on yield, yield components and photosynthesis in Bt transgenic cotton," Journal of Agronomy and Crop Science, vol. 192, no. 2, pp. 132-139, 2006.

[4] K. B. Hebbar, N. K. Perumal, and B. M. Khadi, "Photosynthesis and plant growth response of transgenic Bt cotton (Gossypium hirsutum L.) hybrids under field condition," Photosynthetica, vol. 45 , no. 2, pp. 254-258, 2007.

[5] C. X. Sun, H. Qi, J. Q. Sun, L. L. Zhang, and L. Miao, "Photosynthetic characteristics of Bt or CpTI-Bt transgenic cotton at seedling stage," Acta Agronomica Sinica, vol. 33, no. 3, pp. 469-475, 2007.

[6] W. Ding, K. N. Reddy, R. M. Zablotowicz, N. Bellaloui, and H. Arnold Bruns, "Physiological responses of glyphosate-resistant and glyphosate-sensitive soybean to aminomethylphosphonic acid, a metabolite of glyphosate," Chemosphere, vol. 83 , no. 4 , pp. 593-598, 2011.

[7] N. Cedergreen, C. Felby, J. R. Porter, and J. C. Streibig, "Chemical stress can increase crop yield," Field Crops Research, vol. 114, no. 1, pp. 54-57, 2009.

[8] C. Wendler, M. Barniske, and A. Wild, "Effect of phosphinothricin (glufosinate) on photosynthesis and photorespiration of $\mathrm{C}_{3}$ and $\mathrm{C}_{4}$ plants," Photosynthesis Research, vol. 24, no. 1, pp. 55-61, 1990.

[9] H. A. Bruns and H. K. Abbas, "Comparisons of herbicide treated and cultivated herbicide-resistant corn," International Journal of Agronomy, vol. 2010, Article ID 798127, 7 pages, 2010.

[10] H. A. Bruns, "Stacked-gene hybrids were not found to be superior to glyphosate-resistant or non-GMO corn hybrids," Crop Management, vol. 13, no. 1, 2014.

[11] S. W. Ritchie, J. J. Hanway, and G. D. Benson, How a Corn Plant Develops, Cooperative Extension Service Special Report no. 48, Iowa State University, Ames, Iowa, USA, 1997.
[12] Mississippi State University Extension Service (MSUES), Delta Agricultural Weather Center, Mississippi State University, Starkville, Miss, USA, 2014, http://www.deltaweather .msstate.edu/.

[13] N. Brady, The Nature and Properties of Soils, The MacMillan Company, New York, NY, USA, 9th edition, 1984. 


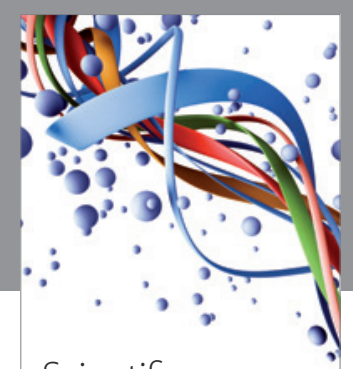

Scientifica
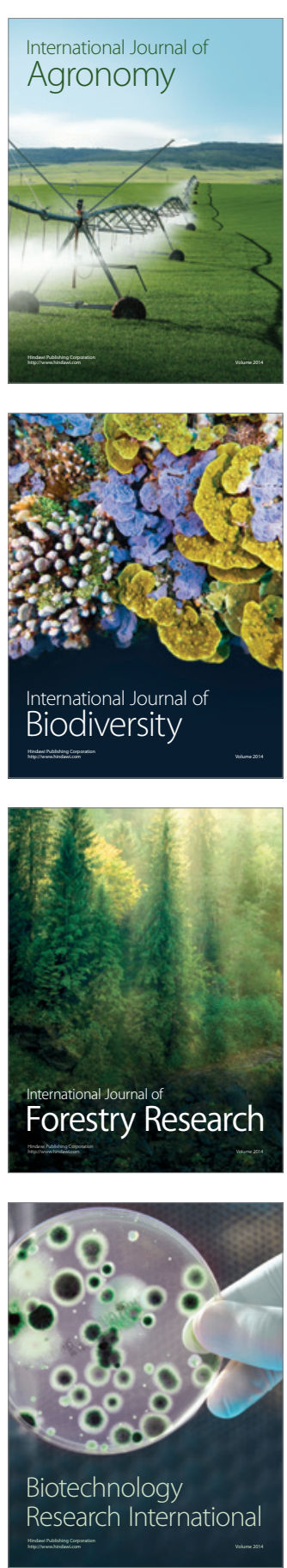
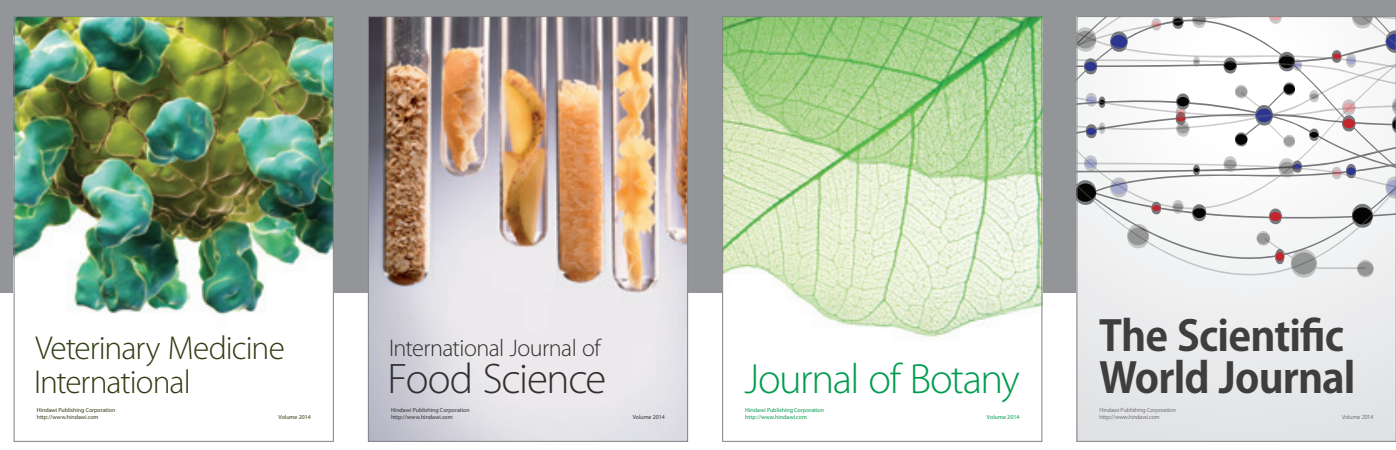

The Scientific World Journal
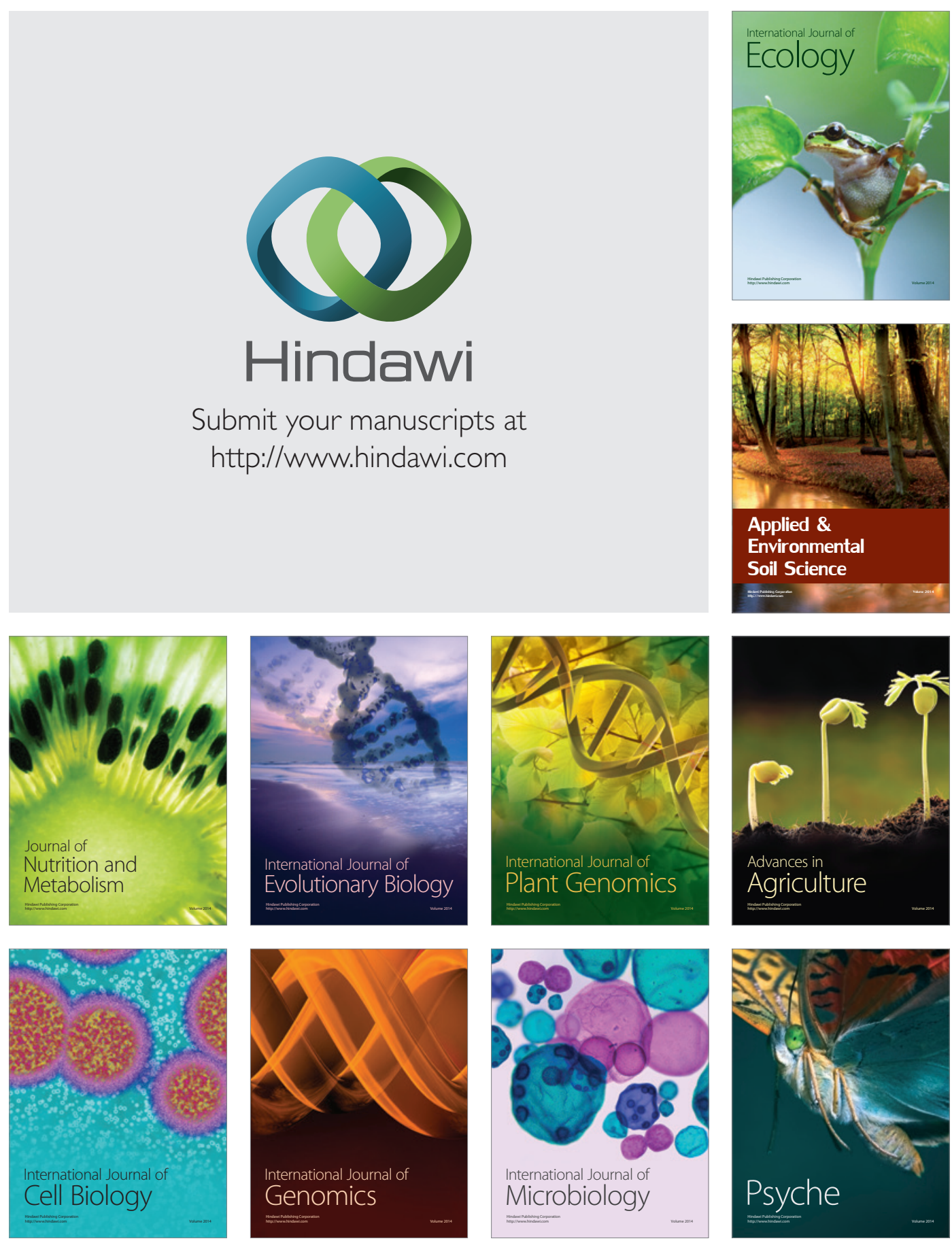